\title{
ANTIEMBRYONIC EFFECT OF BULL SEMINAL VESICLE FLUID IN MICE*
}

\author{
J. MATOUŠEK \\ Laboratory of Animal Genetics, Czechoslovak Academy of Sciences, \\ Libéchov, Czechoslovakia
}

(Received 27th September 1971)

\begin{abstract}
Summary. Subcutaneous injection of the seminal vesicle fluid of bulls into female mice which were subsequently mated resulted in a reduction in the number of embryos. The action of a number of different enzymes on the seminal vesicle fluid did not remove its antifertilizing activity.

The supernatant resulting from precipitation of the seminal vesicle fluid with acetic acid and ammonium sulphate had considerable antifertilizing activity. Injection of this fraction before and after mating demonstrated the antiembryonic character of the antifertilizing substance. Neither the number of ovulated eggs nor their fertilization was affected by the antiembryonic substance and there was no adverse effect on lactation, but the body weight of young, and even of adult, animals declined.

The antiembryonic substance affects the embryo at an early stage and continues to affect the organism for a long time. Necrotic changes can be observed in embryos as early as the 3rd day after the first injection. The number of leucocytes decreases for a short time after injection of the antiembryonic substance.
\end{abstract}

\section{INTRODUCTION}

The aspermatogenic effect of bovine seminal vesicle fluid has been examined in a number of different animal species (Matoušek, 1969; Matoušek, Staněk \& Veselský, 1972) and a preliminary investigation of the antifertilizing effect of this fluid has been carried out in mice and hens (Matoušek \& Petrovská, 1969).

The antifertilizing effect of bovine seminal vesicle fluid is manifested by a reduction in the number of embryos in female mice injected with the fluid before mating. The present study elaborates and extends the findings of the preliminary studies.

\section{MATERIALS AND METHODS}

\section{Collection of fluid}

Bovine seminal vesicle fluid (SVFB) was collected from sexually mature

* This paper reports one part of a project within the International Biological Programme. 
healthy bulls at the slaughterhouse (Matoušek, 1969). Mixtures of SVFB from at least twenty bulls were kept frozen at $-20^{\circ} \mathrm{C}$ until use.

\section{Injection procedure and the determination of embryonic mortality}

The antifertilizing and antiembryonic effect of the vesicular fluid was studied in female mice of the C57BL and CBA strains. The mice were injected subcutaneously with (1) a mixture of SVFB in four doses of $0.05 \mathrm{ml}$ administered in the course of 8 days, 2 to 12 days before mating, (2) a mixture of SVFB treated with enzymes after precipitating the protein by means of alcohol-ether at a ratio of 1:5. The alcohol-ether induced precipitate was resuspended in $0.9 \% \mathrm{NaCl}$ to a protein concentration of 3 to $4 \%$ (determined by the biuret procedure). Three doses of $0.1 \mathrm{ml}$ of this fluid were administered in the course of 6 days, 2 to 12 days before mating and 2 to 7 days after mating, or (3) SVFB fractions were injected in two to five doses of $0.1 \mathrm{ml}$ in the course of 2 to 5 days before and after mating. The fractions were administered by resuspending $10 \mathrm{mg}$ of the dialysed and freeze-dried material in $1 \mathrm{ml} 0.9 \%$ $\mathrm{NaCl}$.

\section{Determination of antifertility and antiembryonic effect}

Mice injected before, and within 6 days after, mating were killed with ether 10 to 12 days after mating. Mice injected between the 7 th and the 14th day of pregnancy were killed 4 days after the last injection and the numbers of live embryos and those which would eventually be aborted were determined at autopsy. Mice injected in the last quarter of pregnancy were not killed and their fertility was determined from the number of offspring born.

The time of mating was determined by the appearance of copulation plugs.

Sensitivity of the antiembryonic substance to the action of enzymes

Bull seminal vesicle fluid was treated with papain, ficin, trypsin, chymotrypsin, pronase, lysozyme, $\alpha$-amylase, $\beta$-amylase and hyaluronidase (KochLight Laboratories Ltd, England) by the method described by Amano \& Behrman (1968). The enzyme concentration used was $20 \mathrm{mg} / \mathrm{ml}$ phosphate buffer, $\mathrm{pH} 7 \cdot 1$. After the enzyme concerned had been allowed to act for $24 \mathrm{hr}$ at $37^{\circ} \mathrm{C}$, an alcohol-ether preparation was added to the mixture of SVFB and enzyme. The resulting precipitate was suspended in $0.9 \% \mathrm{NaCl}$ and used for the study of the antiembryonic effect.

\section{Methods of fractionation of vesicular fluid}

Alcohol-ether. Vesicular fluid was dialysed against phosphate buffer, $\mathrm{pH} 7 \cdot 2$, and the proteins were precipitated by a $3: 1(\mathrm{v} / \mathrm{v})$ ratio of ethanol: ether added to the dialysed vesicular fluid in the ratio of 1:5. The filtered precipitate was air-dried at room temperature and resuspended in $0.9 \% \mathrm{NaCl}$ to a concentration of 3 to $4 \%$ protein.

Ammonium sulphate. Bull seminal vesicle fluid was diluted with an equal part of water and the $\mathrm{pH}$ was adjusted to 7.0 with $1 \mathrm{M}-\mathrm{NaOH}$. Ammonium sulphate was added to a concentration of $3 \mathrm{M}$. After $24 \mathrm{hr}$, the mixture was centrifuged and the precipitate and supernatant were separated. The precipitate was 
dissolved in $0.9 \% \mathrm{NaCl}$, dialysed against water and freeze-dried. The supernatant was also subjected to dialysis and freeze-drying.

Acetic acid and ammonium sulphate. One part of SVFB was diluted by $2 \frac{1}{2}$ parts of $2 \%$ acetic acid and the mixture was allowed to stand for $30 \mathrm{~min}$ at room temperature. After centrifugation, ammonium sulphate was added to the supernatant, to a final concentration of $3 \mathrm{~m}$. After $1 \mathrm{hr}$ at room temperature, the precipitate formed was centrifuged and the supernatant was dialysed and freeze-dried, yielding a basic fraction which was used in subsequent injection procedures.

\section{Electrophoretic analysis of fractions of vesicular fuid}

(1) Starch gel electrophoresis was carried out in a glacial acetic acid +formic acid buffer ( $\mathrm{pH} \mathrm{1.7)}$ according to the method described by Aschaffenburg (1966). Urea ( $47 \mathrm{~g} / 120 \mathrm{ml}$ buffer) was added to prevent formation of protein aggregates. Electrophoresis was run at 300 to $350 \mathrm{~V}$ and 42 to $47 \mathrm{~mA}$ for about $16 \mathrm{hr}$. The gels were cooled with running water.

(2) Disc electrophoresis carried out according to the method described by Ornstein (1964) was used for the investigation of the character of proteins. It was carried out in an apparatus devised by Davis (1964). Standard conditions, i.e. a $7.5 \%$ gel for electrophoresis at $\mathrm{pH} 9.4$ and a $15 \%$ gel for electrophoresis at $\mathrm{pH} 4 \cdot 3$, were utilized, according to instructions provided by the firm Canalco. After dialysis, $0.3 \mathrm{mg}$ dry protein was applied to acrylamide gels which were $0.5 \times 8 \mathrm{~cm}$ in size.

\section{Injection procedures}

(A) Basic fraction, in three doses of $0.1 \mathrm{ml}$ daily $(10 \mathrm{mg}$ protein in $1 \mathrm{ml}$ ), was injected into twenty-nine female mice 2 to 12 days before mating and into 318 females at different periods after mating. In the days following, the females were killed and the number of embryos was determined.

(B) Sixteen female mice were injected in the same way and mated after 3 to 10 days. The females were killed 2 days after mating. The eggs were washed from the oviducts and those at the two-cell stage with a second polar body were regarded as fertilized (Pavlok, 1968).

(C) Basic fraction in five doses of $0.1 \mathrm{ml}$ daily was injected into eight lactating female mice ( 1 to 10 days after the delivery) and into four mice during the last quarter of pregnancy. The offspring were weighed at weekly intervals after the 1st week.

(D) Basic fraction in five doses of $0.1 \mathrm{ml}$ daily was injected into twenty female mice aged 14 to 20 days. Young females were weighed weekly and after achieving a weight of $21 \mathrm{~g}$, they were mated and their fertility was investigated.

(E) Twelve mice were injected daily for 3 days with $0.1 \mathrm{ml}$ basic fraction, beginning on the 4th day after mating. The mice were killed in groups of three on Days 7, 8, 9 and 10 of pregnancy. Twenty-four mice received a similar series of injections starting 8 days after mating. These mice were killed on Days $10,11,12$ and 13 of pregnancy.

(F) Investigation of the dose of basic fraction necessary to produce $100 \%$ 
embryonic mortality was carried out on ninety-six mice. These were injected with 0.2 to $0.5 \mathrm{ml}$ as well as the normal $0.1-\mathrm{ml}$ dose.

(G) Those mice which aborted after the injection of basic fraction were mated again after 20 to 100 days and then killed 10 to 12 days after mating. The number of embryos was recorded.

(H) Sixteen mice were tested 4 days after mating by the addition of $10 \mathrm{mg}$ of basic fraction to the drinking water, and the number of embryos was recorded 12 days after mating.

(I) Basic fraction in five daily doses (1 $\mathrm{mg} /$ day) was injected into twenty-four mice 3 days after mating. Eight control mice received a similar series of injections of $0.9 \% \mathrm{NaCl}$. The mice were decapitated 3 and 10 days after the last injection and blood samples were taken for the determination of the number of

Table 1. Fertility of mice injected with bull seminal vesicle fluid following exposure to the action of various enzymes

\begin{tabular}{l|l|l|l}
\hline \multicolumn{1}{c|}{ Injected fluid } & $\begin{array}{c}\text { Injections } \\
\text { before or } \\
\text { after } \\
\text { mating }\end{array}$ & $\begin{array}{c}\text { No. of } \\
\text { mice } \\
\text { injected }\end{array}$ & $\begin{array}{c}\text { Average no. of } \\
\text { embryos/female }\end{array}$ \\
\hline $0 \cdot 9 \%$ NaCl (Control) & Before & 27 & $6 \cdot 44 \pm 2 \cdot 38$ \\
SVFB+papain & $\begin{array}{l}\text { Before } \\
\text { After }\end{array}$ & 17 & $3 \cdot 06 \pm 3 \cdot 58 * *$ \\
SVFB+ficin & After & 14 & $3 \cdot 76 \pm 3 \cdot 91 * *$ \\
SVFB+trypsin & Before & 36 & $3 \cdot 91 \pm 3 \cdot 72 * *$ \\
SVFB+chymotrypsin & Before & 13 & $3 \cdot 15 \pm 3 \cdot 38 * *$ \\
SVFB+pronase & After & 20 & $3 \cdot 00 \pm 3 \cdot 50^{* *}$ \\
SVFB+lysozyme & Before & 16 & $2 \cdot 75 \pm 3 \cdot 50 * *$ \\
SVFB+ $\alpha$-amylase & After & 51 & $1 \cdot 78 \pm 2 \cdot 72 * *$ \\
SVFB+ $\beta$-amylase & After & 38 & $2 \cdot 21 \pm 3 \cdot 00 * *$ \\
SVFB + hyaluronidase & After & 12 & $4 \cdot 08 \pm 4 \cdot 08$ \\
& After & 12 & $2 \cdot 33 \pm 3 \cdot 10 * *$ \\
\hline
\end{tabular}

SVFB = Bull seminal vesicle fluid.

* Statistically significant, $0.05>P>0.01$.

** Statistically highly significant, $P<0.01$.

red and white blood cells and for differential white blood cell determination. Differential counts of 100 to 200 cells were made on smears stained with MayGrünwald's and Giemsa's stain.

\section{RESULTS}

Antifertilizing effect of the seminal vesicle fluid of bulls

The subcutaneous injections of SVFB into female mice mated 2 to 10 days after the last injection resulted in a reduction in the number of embryos. In twenty mice injected with SVFB, seventy-one embryos were detected on the 12 th day of the pregnancy while, in twenty mice injected with $0.9 \% \mathrm{NaCl}, 144$ embryos were found $(3.55 \pm 3.20$ and $7.02 \pm 1.40 /$ female $)$. In eight mice, the 
SVFB of sexually immature bulls did not evoke any reduction in the number of embryos $(6 \cdot 25 \pm 1 \cdot 95 /$ female $)$.

None of the enzymes used succeeded in abolishing the antifertilizing activity of SVFB, and only $\alpha$-amylase effected a reduction in activity (Table 1 ).

After dialysis and precipitation of the protein fraction by alcohol-ether, the antifertilizing substance was found in the precipitate. Ten mice injected with the precipitate had forty-three embryos at 12 days of pregnancy, while females injected with the supernatant had seventy-seven embryos.

The active substance occurred in both the ammonium sulphate supernatant and the precipitate. The mean number of embryos in thirty-one mice injected with freeze-dried precipitate amounted to $3 \cdot 22 \pm 3 \cdot 16 /$ female. Injections of the supernatant material reduced the number of embryos in sixteen mice to $2 \cdot 50 \pm 3 \cdot 43 /$ mouse. Acetic acid $(2 \%)$ precipitated some non-reactive proteins but in combination with ammonium sulphate, the very active (Table 2)

Table 2. Antiembryonic activity of the basic fraction in the supernatant of bull vesicular fluid following precipitation by acetic acid and ammonium sulphate

\begin{tabular}{|c|c|c|}
\hline Time of first injection & $\begin{array}{c}\text { No. of mice } \\
\text { injected }\end{array}$ & $\begin{array}{l}\text { Average no. of } \\
\text { embryos/female }\end{array}$ \\
\hline $\begin{array}{l}\text { Control } 0.9 \% \text { NaCl } \\
2 \text { to } 10 \text { days before mating } \\
\text { On the day of mating } \\
1 \text { day after mating } \\
2 \text { days after mating } \\
3 \text { days after mating } \\
4 \text { days after mating } \\
5 \text { days after mating } \\
6 \text { days after mating } \\
7 \text { days after mating } \\
8 \text { days after mating } \\
9 \text { days after mating } \\
10 \text { days after mating } \\
11 \text { days after mating } \\
12 \text { days after mating } \\
13 \text { days after mating } \\
14 \text { days after mating } \\
15 \text { days after mating } \\
16 \text { days after mating } \\
17 \text { days after mating }\end{array}$ & $\begin{array}{l}12 \\
29 \\
12 \\
13 \\
12 \\
17 \\
54 \\
43 \\
13 \\
26 \\
12 \\
13 \\
11 \\
11 \\
15 \\
11 \\
26 \\
13 \\
7 \\
9\end{array}$ & $\begin{array}{l}5 \cdot 75 \pm 1 \cdot 90 \\
2 \cdot 65 \pm 3 \cdot 17 * * \\
1 \cdot 16 \pm 1 \cdot 90 * * \\
2 \cdot 23 \pm 3 \cdot 01 * * \\
3 \cdot 08 \pm 3 \cdot 58 * \\
0 \cdot 17 \pm 0 \cdot 32 * * \\
1 \cdot 37 \pm 2 \cdot 10^{* *} \\
1 \cdot 30 \pm 2 \cdot 05 * * \\
1 \cdot 00 \pm 1 \cdot 90^{* *} \\
2 \cdot 57 \pm 2 \cdot 80^{* *} \\
2 \cdot 66 \pm 2 \cdot 08 * \\
1 \cdot 92 \pm 2 \cdot 70^{* *} \\
3 \cdot 09 \pm 3 \cdot 36^{*} \\
2 \cdot 36 \pm 2 \cdot 75 * \\
2 \cdot 20 \pm 2 \cdot 91 * * \\
1 \cdot 72 \pm 2 \cdot 50 * * \\
4 \cdot 72 \pm 2 \cdot 61 \\
4 \cdot 77 \pm 2 \cdot 96 \\
5 \cdot 57 \pm 1.92 \\
6 \cdot 11 \pm 1 \cdot 67\end{array}$ \\
\hline
\end{tabular}

* Statistically significant, $0.05>P>0.01$.

** Statistically highly significant, $P<0.01$.

supernatant basic fraction was obtained. Its partial purification and concentration in the active substance $\mathrm{A}$ can be seen in Plate 1 and Text-fig. 1.

\section{Mode of action of the antifertilizing substance in bull seminal vesicle fluid}

Even after treatment with enzymes, injections of SVFB before and after mating (Table 1) demonstrated the probable antiembryonic character of the antifertilizing substance. Injections of the partially purified basic fraction supported this observation. Females receiving the basic fraction in three doses of $0.1 \mathrm{ml}$ daily from the day of the mating till the 13th day of the pregnancy showed a significant increase in embryonic mortality (Table 2), while injections 

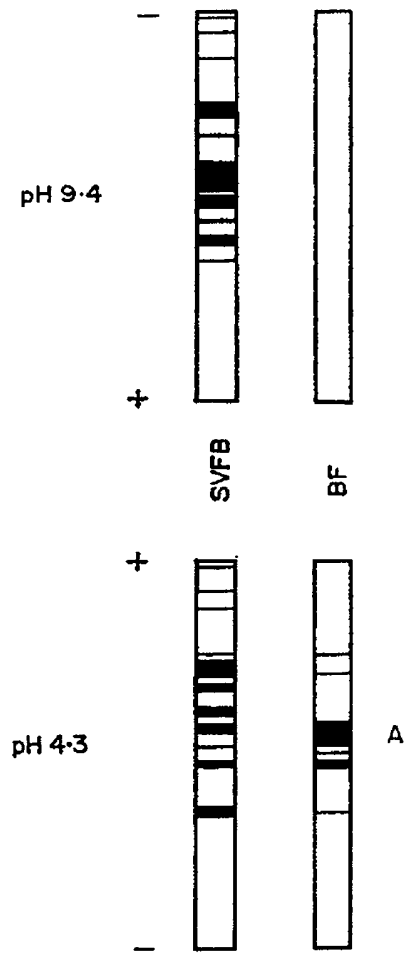

TExT-FIG. 1. Disc electrophoresis of the seminal vesicle fluid of bulls (SVFB) and the basic fraction of this fluid (BF) at $\mathrm{pH} 9 \cdot 4$ and $\mathrm{pH} 4 \cdot 3$. A = antiembryonic active fraction.

Table 3. Development of zygotes in mice injected with the basic fraction in the supernatant of bull vesicular fluid following precipitation by acetic acid and ammonium sulphate

\begin{tabular}{|c|c|c|c|c|}
\hline \multirow{2}{*}{$\begin{array}{c}\text { Day of mating } \\
\text { after last } \\
\text { injection }\end{array}$} & \multirow{2}{*}{$\begin{array}{c}\text { No. of } \\
\text { mice } \\
\text { injected }\end{array}$} & \multicolumn{3}{|c|}{ No. of eggs } \\
\hline & & Total & Two blastomeres & Uncleaved \\
\hline $\begin{array}{r}3 \\
4 \\
5 \\
6 \\
7 \\
8 \\
9 \\
10\end{array}$ & $\begin{array}{l}1 \\
3 \\
5 \\
2 \\
1 \\
1 \\
1 \\
2\end{array}$ & $\begin{array}{r}11 \\
23 \\
43 \\
19 \\
10 \\
7 \\
8 \\
14\end{array}$ & $\begin{array}{r}11 \\
23 \\
40 \\
19 \\
10 \\
7 \\
8 \\
12\end{array}$ & $\begin{array}{l}0 \\
0 \\
3 \\
0 \\
0 \\
0 \\
0 \\
2\end{array}$ \\
\hline $\begin{array}{l}\text { Total } \\
\text { Average/female }\end{array}$ & 16 & $\begin{array}{c}135 \\
8 \cdot 43 \pm 1 \cdot 11\end{array}$ & $\begin{array}{c}130 \\
8 \cdot 12 \pm 1.03\end{array}$ & $\begin{array}{c}5 \\
0.31 \pm 0.27\end{array}$ \\
\hline
\end{tabular}




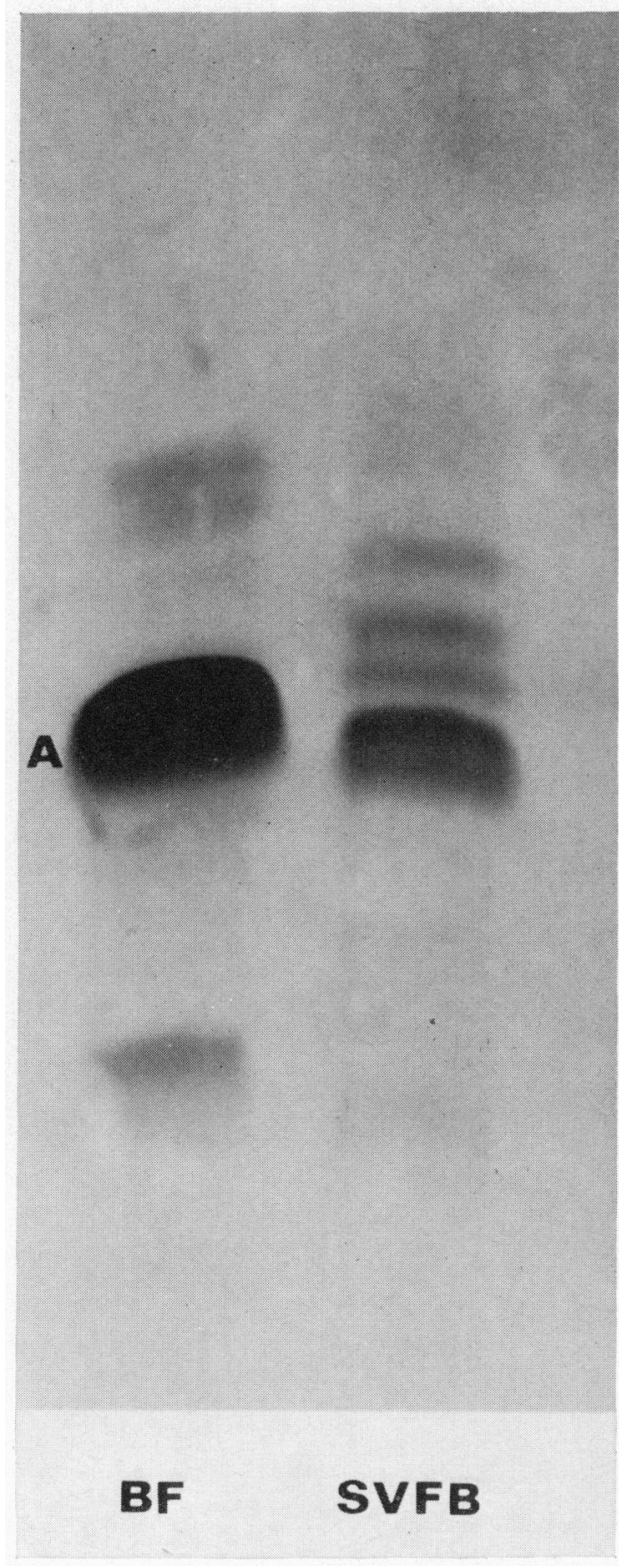

Starch-gel electrophoretic separation of the seminal vesicle fluid of bulls (SVFB) and the basic fraction of this fluid $(\mathrm{BF}) . \mathrm{A}=$ antiembryonic active fraction. 
which were not begun until the 14th, and especially 16 th and 17 th days, were ineffective.

Neither the number of eggs ovulated nor their fertilization was affected by the active substance. The mean numbers of two-blastomere embryos in sixteen mice injected 3 to 10 days before mating were $8 \cdot 12 \pm 1.03$ (Table 3 ). The onset of oestrus in the injected females was not changed when compared to that in control animals.

The antiembryonic substance did not appear to have any effect on the lactation of suckling females. There was no difference in the weight of fiftyeight offspring of eight females, which were injected with increased doses of the basic fraction at the beginning of lactation, compared with that of the offspring of control mice. (The average body weight for experimental mice at the age of 6 weeks was $20.60 \pm 1.70 \mathrm{~g}$, and that for control mice was $20.21 \pm$ $1.71 \mathrm{~g})$. Neither the body weight $(20.32 \pm 0.88 \mathrm{~g})$ nor the fertility $(8.23 \pm 2.31$ offspring/mouse) was affected.

Injections of the basic fraction given to twenty females at the age of 14 to 20 days significantly decreased their weight increase. The average body weight for the injected mice was $17.50 \pm 1.80 \mathrm{~g}$. The difference compared with the control group $(20.21 \pm 1.71 \mathrm{~g})$ is statistically very significant $(P<0.001)$. A similar weight decrease (about $10 \%$ ) was noticed after injections of the antiembryonic substance into adult mice. Even those mice which were injected with the basic fraction at the age of 14 to 20 days or in maturity showed no essential health disturbances or increased mortality. Twenty mice which were injected in youth showed no increase of embryonic mortality when sexual maturity was reached 25 to 35 days after the end of the injections. The average number of embryos on the 12 th day of pregnancy was $7 \cdot 16 \pm 0 \cdot 80$.

The active antiembryonic substance affects the embryo very early. It is possible to observe necrotic changes in embryos on the 3rd day after the first injection. When the basic fraction is administered up to the 5th day after mating, the death of the blastocysts probably occurs immediately after, or even before, nidation since, from the 7th day after mating, no blastocyst traces can be seen and the uteri have a normal non-pregnant appearance. In twenty-four mice which received their first injection 8 days after mating, 134 embryos were found on the 10th to 13th days of pregnancy and, of these, 112 were aborted and only twenty-two were normal.

In an investigation of the effects of various doses of the basic fraction on embryonic mortality, it was found that injection of $2 \mathrm{mg}$ per female resulted in an average of only $1 \cdot 17 \pm 1.79$ live embryos/mouse for twenty-three mice, $3-\mathrm{mg}$ resulted in an average of $1.21 \pm 1.89$ /mouse for thirty-two mice, $4 \mathrm{mg}$ resulted in the death of all the embryos in twenty-two mice and $5 \mathrm{mg}$ produced sterility in eighteen out of nineteen mice.

From the results of the study of embryonic mortality in mice injected 10 or more days before mating and from the fertility results in 155 mice which aborted after basic fraction injections and which, at different periods after abortion, were mated again, the antiembryonic substance appears to be effective in mice for a relatively long time. Repeated and highly significant embryonic mortality occurs for the second time in mice injected between 20 
and 25 days after the end of the injections. A significant $(P=0.05$ to 0.01$)$ decrease of fertility is apparent up to 50 days from the last injection (Table 4).

By contrast, the addition of basic fraction to the drinking water in a double dose $(10 \mathrm{mg} /$ mouse) was ineffective. In sixteen mice treated in this way, the average number of embryos per mouse was 5.87 \pm 3.03 .

Injections of the basic fraction did not affect the average number of erythrocytes either in a group of twelve mice killed 3 days after the end of the injections $(5,796,000 \pm 775,000)$ or in twelve mice decapitated 10 days after receiving the injections $(5,994,000 \pm 516,000)$ when these levels were compared with those of controls $(5,517,000 \pm 775,000)$. The number of leucocytes was decreased $(P=0.05$ to 0.02$)$ in twelve experimental mice killed 3 days after the final

Table 4. Embryonic mortality of mice rendered temporarily sterile after injections of the antiembryonic active fraction and secondarily mated again after various time intervals

\begin{tabular}{l|c|c}
\hline $\begin{array}{c}\text { No of days from the } \\
\text { iast injection to } \\
\text { the second mating }\end{array}$ & $\begin{array}{c}\text { No. of mice } \\
\text { mated }\end{array}$ & $\begin{array}{c}\text { Average no. of } \\
\text { embryos/female }\end{array}$ \\
\hline Control & 14 & $6 \cdot 07 \pm 2 \cdot 14$ \\
20 to 25 & 15 & $1 \cdot 46 \pm 2 \cdot 12^{* *}$ \\
26 to 30 & 37 & $3 \cdot 40 \pm 3 \cdot 50^{*}$ \\
31 to 35 & 14 & $3 \cdot 87 \pm 3 \cdot 16^{*}$ \\
36 to 40 & 13 & $3 \cdot 14 \pm 2 \cdot 18^{*}$ \\
41 to 50 & 11 & $3 \cdot 61 \pm 3 \cdot 55$ \\
51 to 60 & 11 & $5 \cdot 54 \pm 2 \cdot 68$ \\
61 to 70 & 15 & $5 \cdot 20 \pm 2 \cdot 64$ \\
71 to 80 & 17 & $5 \cdot 64 \pm 2 \cdot 65$ \\
80 to 100 & & \\
\hline
\end{tabular}

* Statistically significant, $0.05>P>0.01$.

** Statistically highly significant, $P<0.01$.

basic fraction injections $(2962 \pm 675$ compared to the control level of $4118 \pm$ 1087), but not in mice killed 10 days after the injections (4223 \pm 816$)$. Differential white blood cell values were not changed significantly $(77 \pm 8 \%$ of lymphocytes and $23 \pm 8 \%$ of heterophils in the group of mice killed 3 days after the last injections, $84 \pm 7 \%$ lymphocytes and $16 \pm 7 \%$ heterophils in the mice killed 10 days after the injections, and $81 \pm 7 \%$ lymphocytes and $19 \pm 7 \%$ heterophils in the control group).

\section{DISCUSSION}

The results presented in this paper indicate that the so-called antifertilizing substance of the seminal vesicle fluid of bulls (Matoušek \& Petrovská, 1969) has such an effect only after fertilization of the egg. It does not disrupt the oestrous cycle, ovulation or the actual fertilization process, as may be inferred from the undisturbed development of the zygote at the two-blastomere stage in mice injected 3 to 10 days before mating. The embryonic mortality observed in mice injected after mating is further proof of the specific teratogenic effect aimed at the developing embryo. 
An interesting problem is the relative ineffectiveness of the antiembryonic substance on embryos in the last quarter of their development. It is possible that the antiembryonic substance does not have enough time to evoke the damage (even when in younger embryos, the damage occurs several hours after injection of the active substance) or that, in this developmental stage of the embryo, some barriers are present which do not allow the substance to act effectively. The possibility cannot be excluded that the antiembryonic substance attaches itself to a component of the embryo which is present only during a certain period of embryonic development.

There appears to be no disturbance of the oestrous cycle, ovulation or lactation and it may be presumed that the antiembryonic substance does not interfere with the hormonal activity of the individual.

The embryonic mortality is unlikely to have an immunological origin. Embryonic damage occurs very early after the injection of the active substance when antibodies cannot have been fully formed. In experiments with rabbits, no difference in the quantity and quality of antibodies was found between injected females whose embryos had been aborted and those whose embryos developed normally ( $\mathrm{J}$. Matoušek, unpublished results). The immunological situation seems to be the same as in males receiving injections of the aspermatogenic factor (Matoušek et al., 1972).

The antiembryonic substance affects the mouse organism for a relatively long time. This suggests the possibility of a specific teratogen circulating in the maternal blood or bound to maternal tissues and released to become effective when the embryonic cells undergo development.

The effective factor in the antiembryonic substance is unknown. In general, cell cleavage or the metabolic processes specific to the embryonic tissues can be disturbed in the blastocyst either before or after nidation. However, it seems unlikely that this substance would be effective as a common cytostatic agent. It is true that the number of leucocytes after injections of the antiembryonic substance was significantly decreased, but only for a few days and the differential white blood cell count of heterophils and lymphocytes was practically not affected at all. The accompanying digestive disorders typical for cytostatic agents were not observed.

The antiembryonic substance may be identical with the aspermatogenic factor of the seminal vesicle fluids of bulls (Matoušek, 1969; Matoušek et al., 1972). All fractions which have an active aspermatogenic effect also appear to be active from the antiembryonic aspect ( $J$. Matoušek, unpublished results). The position and character of the presumed aspermatogenic and antiembryonic fractions on electrophoretograms are identical.

\section{ACKNOWLEDGMENTS}

For the isolation of mouse eggs and the determination of the stage of their cleavage, the author is especially grateful to Dr A. Pavlok. For technical assistance, gratitude is due to Miss J. Janatková and Miss L. Zemanová. 


\section{REFERENCES}

Amano, V. \& BeHRMAN, S. J. (1968) Immunochemical studies on human seminal plasma. II. Isolation and characterization of major antigens. Int. F. Fert. 13, 61.

Aschaffendurg, R. (1966) Modified procedure of starch gel electrophoresis for $\beta$-casein phenotyping. 7. Dairy Sci. 49, 1284.

DAvis, B. J. (1964) Disc electrophoresis. II. Method and application to human serum proteins. Ann. N.r. Acad. Sci. 121, 404.

MATOUŠEK, J. (1969) Effects on spermatogenesis in guinea-pigs, rabbits and sheep after their immunization with sexual organ fluids of bulls. F. Reprod. Fert. 19, 63.

MAtoušse, J. \& Petrovská, E. (1969) Antifertilizing effect of the seminal vesicle fluid of bulls on females. F. Reprod. Fert. 20, 189.

MAtoušk, J., StanĚK, R. \& Veselskí, L. (1972) First attempt to characterize an aspermatogenic substance in the seminal vesicle fluids of bulls. F. Reprod. Fert. 29, 179.

Ornstein, L. (1964) Disc electrophoresis. I. Background and theory. Ann. N.Y. Acad. Sci. 121, 321.

Pavlok, A. (1968) Fertilization of mouse ova in vitro. I. Effect of some factors on fertilization. $\mathcal{F}$. Reprod. Fert. 16, 401. 